\title{
WOOD ANATOMY OF ONAGRACEAE: ADDITIONAL SPECIES AND CONCEPTS ${ }^{1}$
}

\author{
Sherwin Carlquist ${ }^{2}$
}

\begin{abstract}
Wood anatomy of Epilobium colchicum subsp. colchicum, Fuchsia excorticata, and Hauya heydeana is described qualitatively and quantitatively. For the latter two species, large logs were available and wood portions from both inside and outside were analyzed. Although these three species offer no features new for Onagraceae, each adds features new for its respective genus. By means of numerical indices which are termed vulnerability and mesomorphy, respectively, values are presented to show the range in ecological characteristics of woods of the three species, as well as of all Onagraceae studied earlier. Onagraceae show a wide range in these indices and probably form a good model of what use indices in families with a broad ecological range will demonstrate. Wood from inside of logs of Fuchsia excorticata and Hauya heydeana is more xeromorphic than wood from the periphery.
\end{abstract}

In my monograph of wood anatomy of Onagraceae (Carlquist, 1975a), I attempted a sampling of woods based largely on availability of portions of suitable size. In any family in which herbs predominate, one is faced with arbitrary decisions as to whether some species which form little secondary xylem should be included. However, after the appearance of the monograph, Dr. Peter H. Raven placed at my disposal three wood samples with abundant secondary xylem for their respective genera, and otherwise of more than passing interest.

\section{Materials and Methods}

Epilobium colchicum Alboff subsp. colchicum (sect. Chamaenerion) was collected by Dr. Peter H. Raven from a streambed near the Lagodekhi Hotel in eastern Georgia, U.S.S.R., and is unusually woody for an Epilobium. The species of Fuchsia that forms perhaps the largest trees in that genus (and perhaps also in the family) is F. excorticata (J. R. \& G. Forst.) L. f. A section from the base of a tree approximately $0.9 \mathrm{~m}$ in diameter (outline of section irregular) was supplied by the New Zealand Institute of Forestry. Dr. Dennis E. Breedlove's mesoamerican field work yielded a $\log$, approximately $25 \mathrm{~cm}$ in diameter, of Hauya heydeana Donnell Smith. Because all the Hauya wood samples utilized in my earlier study were of $H$. elegans subsp. cornuta, material of the second species of this interesting genus was especially welcome. All three wood samples were dried. Methods of study were the same as those employed for dried samples in the earlier paper. Dr. Larry DeBuhr's work in preparing sections and macerations and in obtaining data is gratefully acknowledged. Because differences in wood anatomy were observed (Carlquist, 1975a) in samples of different diameter in Hauya elegans subsp. cornuta, both inner and outer portions of

\footnotetext{
${ }^{1}$ This study has been aided by a grant from the National Science Foundation, BMS 7307055-A1. The wood of Fuchsia excorticata was provided by Dr. E. J. Godley, D.S.I.R., Christchurch, New Zealand.

${ }^{2}$ Claremont Graduate School, Pomona College, and Rancho Santa Ana Botanic Garden, Claremont, California 91711.
}

Ann. Missouri Bot. Gard. 64: 627-637. 1977. 


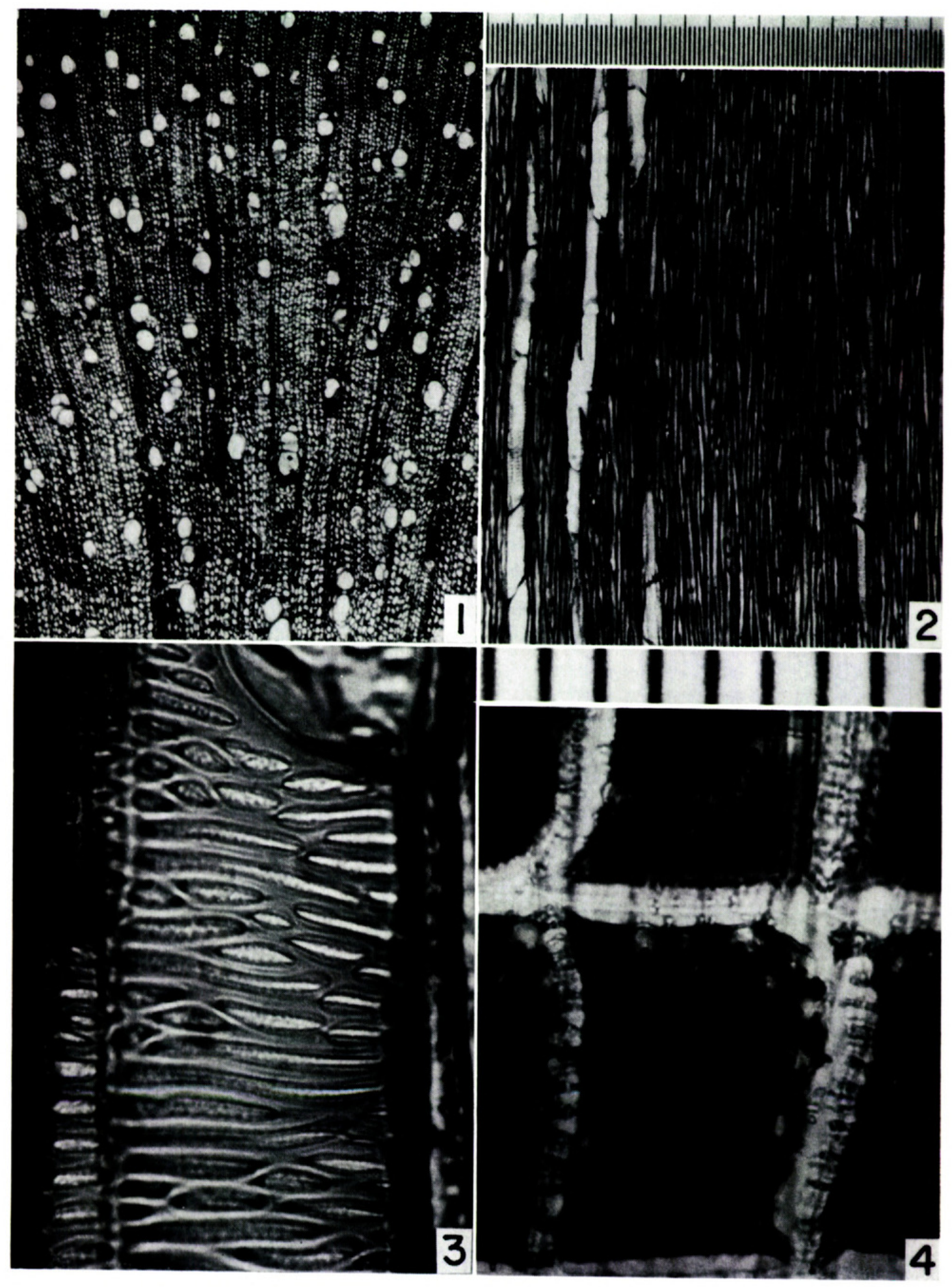

Figures 1-4. Wood sections of Epilobium and Hauya.-1-3. Epilobium colchicum Alboff subsp. colchicum, Raven 26519 (MO).-1. Transection; parenchyma bands not shown in this photograph.-2. Tangential section; rays few, inconspicuous.-3. Portion of vessel wall from tangential section.-4. Hauya heydeana Donnell Smith, Breedlove 15653 (MO). Radial section of ray cells showing nature of walls and starch grains embedded in dark-staining amorphous materials. [Magnification indicated by photograph of stage micrometer enlarged at same scale as applicable photomicrographs. Figs. 1-2, scale above Fig. 2 (finest divisions = $10 \mu \mathrm{m})$. Figs. 3-4, scale above Fig. 4 (divisions $=10 \mu \mathrm{m})$.] 
the logs of Fuchsia excorticata and Hauya heydeana were studied. Quantitative data for both portions are reported below. Qualitative features of inner and outer portions are the same unless otherwise mentioned.

\section{Anatomical Descriptions}

Epilobium colchicum subsp. colchicum, Raven 26519 (MO), Figs. 1-3. Growth rings present as parenchyma bands that are discontinuous in places around the stem. Mean vessel diameter, $50 \mu \mathrm{m}$; mean vessel element length, 184 $\mu \mathrm{m}$. Vessels mostly solitary (Fig. 1); if grouped, in radial chains or multiples; mean number of vessels per group 1.36. Mean number of vessels per $\mathrm{mm}^{2}$ of transection 38.1. Perforation plates simple. Lateral wall pitting of vessels basically alternate, appearing somewhat scalariform because pits are laterally elongate (Fig. 3). Pits conspicuously vestured (Fig. 3). Mean libriform fiber length $277 \mu \mathrm{m}$. Mean libriform fiber wall thickness $1.6 \mu \mathrm{m}$. Libriform fiber walls not gelatinous; pits simple. Axial parenchyma in the form of bands, with also a few vasicentric cells forming strands of one to three cells. Bands of axial parenchyma probably contain interxylary phloem, but determination uncertain because of lack of liquid preservation. Multiseriate rays more frequent than uniseriates, but both inconspicuous (Fig. 2) because upright cells predominate in multiseriates, with only a few square and procumbent cells. Uniseriate rays consist of upright cells only. Mean height of multiseriate rays $567 \mu \mathrm{m}$; uniseriates, $84 \mu \mathrm{m}$. Ray cells thin to moderately thick, the latter sometimes with bordered pits. No crystals observed. Amorphous deposits of dark-staining materials in some ray cells (Fig. 1). Wood not storied.

Fuchsia excorticata, Figs. 5-8. Growth rings inconspicuous in inner wood (Fig. 5), with narrower vessels in latewood, wider vessels in earlywood. Growth rings not evident in outer wood. Mean vessel diameter $73 \mu \mathrm{m}$ in outer wood, $63 \mu \mathrm{m}$ in inner wood. Mean vessel element length $325 \mu \mathrm{m}$ in outer wood, 259 $\mu \mathrm{m}$ in inner wood. Vessels solitary or in multiples (Fig. 5), averaging 1.52 per group in outer wood, 1.76 per group in inner wood. Mean number of vessels per $\mathrm{mm}^{2}$ of transection 32 in outer wood, 57 in inner wood. Perforation plates simple. Tyloses present in vessels, numerous, thin-walled (Fig. 6, right). Lateral wall pitting of vessels (Fig. 8) consists of alternate pits, angular and rhomboidal in outline or laterally elongate. Pits conspicuously vestured. Mean libriform fiber length $598 \mu \mathrm{m}$ in outer wood, $562 \mu \mathrm{m}$ in inner wood. Libriform fiber wall thickness $2.5 \mu \mathrm{m}$ in outer wood, $2.9 \mu \mathrm{m}$ in inner wood. Libriform fiber walls not noticeably gelatinous. Libriform fibers prominently septate (Fig. 7). Extremely minute vestiges of borders observed on pits of some libriform fibers (Fig. 7). Interxylary phloem absent. Axial parenchyma scanty vasicentric; strands consisting of three to five cells per strand. Rays predominantly multiseriate (Fig. 6); uniseriates infrequent, virtually absent in inner wood. Mean multiseriate ray height $755 \mu \mathrm{m}$ in outer wood, $494 \mu \mathrm{m}$ in inner wood; uniseriates (outer wood), $224 \mu \mathrm{m}$. Multiseriates composed of upright, square and procumbent cells. Uniseriates composed wholly of erect cells. No crystals observed. A few ray cells with dark-staining contents (Fig. 6). Wood not storied. 


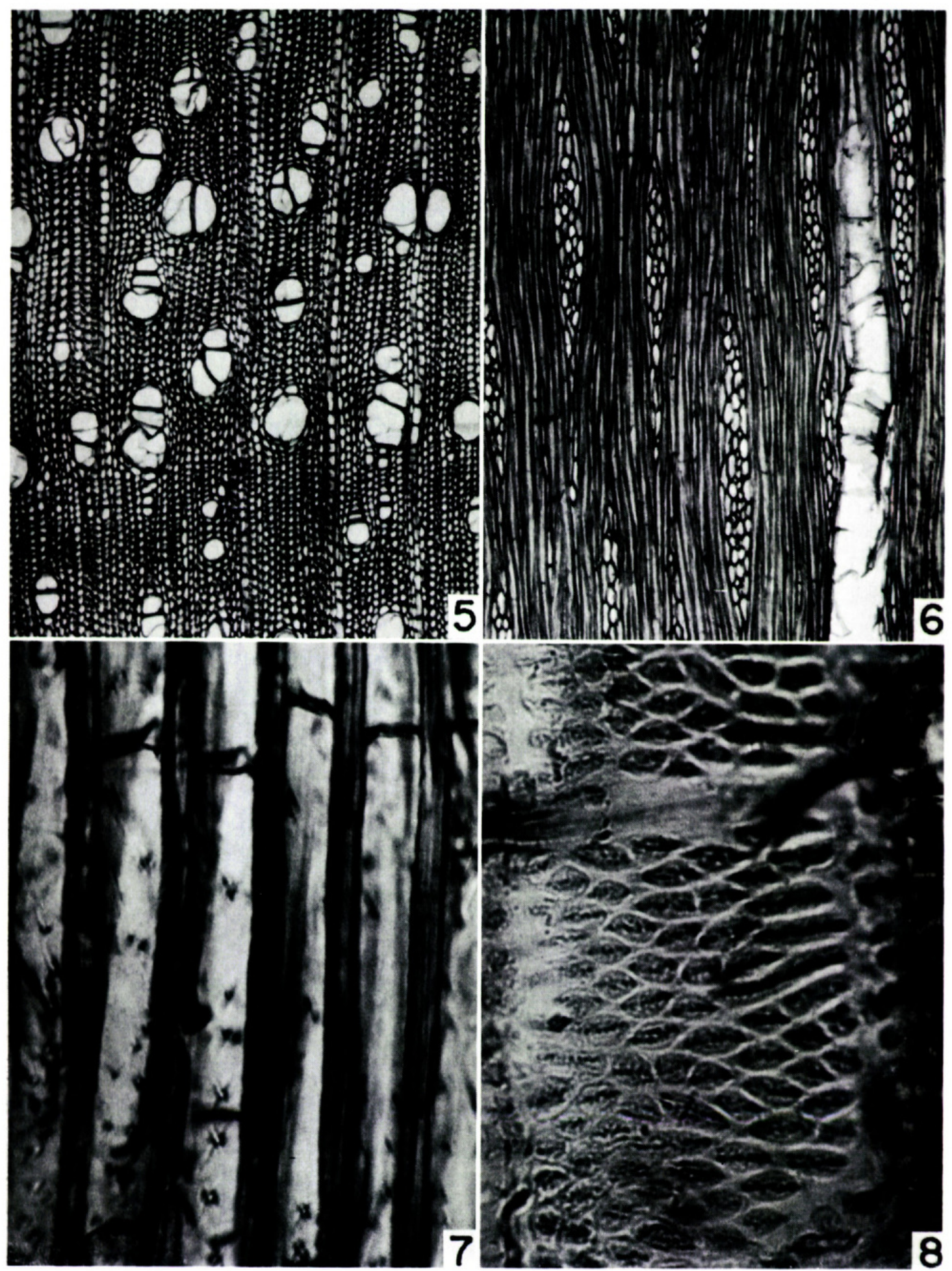

Figures 5-8. Wood sections of Fuchsia excorticata (J. R. \& G. Forst.) L. f., collected by the New Zealand Forestry Institute.-5. Transection, from near center of large log.-6. Tangential section, from near periphery of large log.-7. Septate fibers, showing pitting, from radial section.-8. Vessel wall from radial section, showing vestured pits, angular in outline, some laterally elongate. [Magnification for Figs. 5-6, shown above Fig. 2. Scale for Figs. $7-8$, shown above Fig. 4.] 
Hauya heydeana, Breedlove 15653 (MO), Figs. 4, 9-12. Growth rings inconspicuous, vessels wider in earlywood (Fig. 9). Mean vessel diameter $111 \mu \mathrm{m}$ in outer wood, $80 \mu \mathrm{m}$ in inner wood. Mean vessel element length $506 \mu \mathrm{m}$ in outer wood, $481 \mu \mathrm{m}$ in inner wood. Vessels mostly grouped in short radial chains (Fig. 9), 2.52 per group in outer wood, 2.24 in inner wood. Mean number of vessels per $\mathrm{mm}^{2}$ of transection 31 in outer wood, 56 in inner wood. Perforation plates simple. Lateral wall pitting of vessels alternate, pits round in outline with some tendency toward laterally elongate pits. Vesturing on pits not readily visible. Mean length of libriform fibers $874 \mu \mathrm{m}$ in outer wood, $903 \mu \mathrm{m}$ in inner wood. Mean libriform fiber wall thickness $2.5 \mu \mathrm{m}$ in outer wood, $2.0 \mu \mathrm{m}$ in inner wood. Libriform fibers with inner portion of wall markedly gelatinous (Fig. 10). Axial parenchyma mostly vasicentric, but with some cells in tangential bands (Figs. $9,10,12$ ), as in H. elegans subsp. cornuta; parenchyma cells consist of two or three cells per strand. No interxylary phloem present. Both multiseriate and uniseriate rays present (Figs. 11-12). Mean multiseriate ray height $497 \mu \mathrm{m}$ in outer wood, $609 \mu \mathrm{m}$ in inner wood. Mean uniseriate ray height $352 \mu \mathrm{m}$ in outer wood, $305 \mu \mathrm{m}$ in inner wood. Both multiseriate and uniseriate rays consisting of upright, square and procumbent cells. Ray cell walls thick (Fig. 4), some with bordered pits. Massive deposits of dark-staining materials in ray cells and axial parenchyma (Figs. 4, 9-10, 12). Starch grains also present in ray cells (Fig. 4) and axial parenchyma cells. Wood not storied.

\section{Comparisons}

Epilobium colchicum (sect. Chamaenerion), a woody perennial, differs from E. paniculatum (sect. Xerolobium), a rank annual, most notably in the presence of axial parenchyma bands (Carlquist, 1975a). Phloem is presumptively present in these bands. Because these bands do not extend all the way around the stem, the apparent absence of cork cells, such as reported by Moss (1936) in Epilobium angustifolium (also of sect. Chamaenerion), is understandable. Epilobium colchicum shows laterally widened pits on the vessel walls (Fig. 3) with exceptional clarity. These pits are very clearly vestured. Species of the tribe Epilobieae do not, in wideness of vessels, length of vessel elements, and low number of vessels per $\mathrm{mm}^{2}$ of transection, approach the two species of Hauya. Still, one may note that E. colchicum has the most mesomorphic woods of the three species of Epilobieae now studied. In view of its riparian habitat, which contrasts strongly with the xeric habitats of the other two species, this correlation is logical.

Fuchsia excorticata falls within the range of wood features reported for Fuchsia earlier. Scanning electron micrographs of the vestured pits of $F$. excorticata have been presented by Butterfield \& Meylan (1973). The potential interest of F. excorticata in relation to wood anatomy of Onagraceae is whether, with trunks of such large size, changes in quantitative characteristics occur with age. As the above descriptions indicate, some changes do occur. Vessel elements are appreciably wider, longer, and few per $\mathrm{mm}^{2}$ in the outer wood than in the inner wood. Libriform fibers are longer and slightly more thin-walled in the outer wood. Multiseriate rays are taller in the outer wood. Although ray histology 


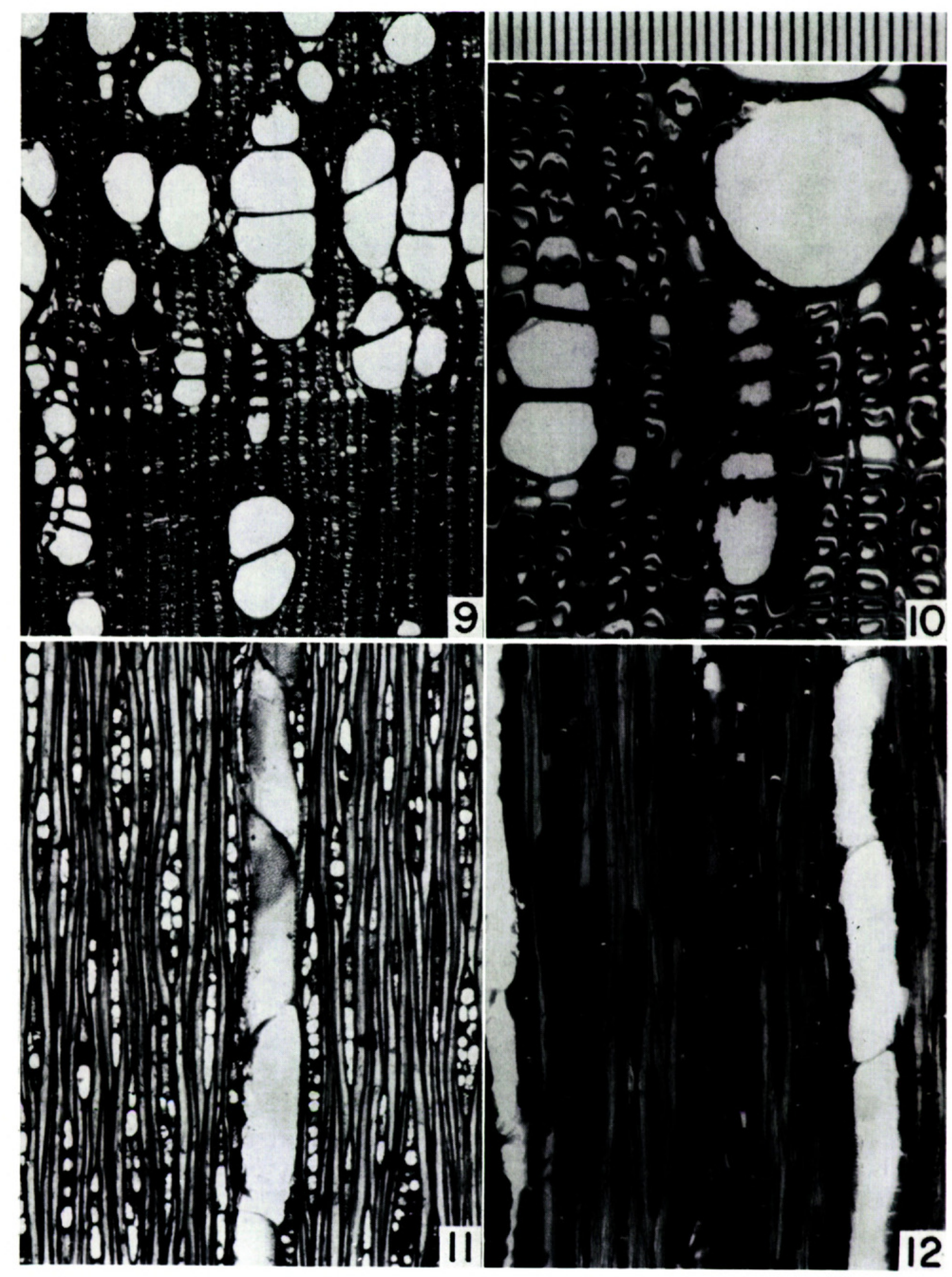

Figunes 9-12. Wood sections from periphery of log of Hauya heydeana Donnell Smith, Breedlove 15653 (MO)._-9. Transection, showing a growth ring.-10. Transection, enlarged, showing gelatinous walls of libriform fibers, dark-staining contents of parenchyma cells, and distribution of axial parenchyma.-11. Tangential section, showing nature of rays. - 12. Another tangential section, showing massive deposits of gummy materials in rays, axial parenchyma. [Scale for Figs. 9, 11-12, shown above Fig. 2. Scale for Fig. 10 above Fig. 10.] 
does not seem to change, there is a change in presence of uniseriate rays. In the outer wood of F. excorticata (Fig. 6), uniseriates are present, whereas they can be said to be virtually absent in the inner wood. This is exceptional in Fuchsia, although in most species studied, multiseriates do predominate over uniseriates (Carlquist, 1975a). The quantitative changes with age are in accordance with those one expects in a typical woody dicotyledon (Bailey \& Tupper, 1918; Carlquist, 1975b).

Hauya heydeana differs in some features of wood anatomy from the species studied previously, H. elegans subsp. cornuta. Most notable are the ergastic materials. Whereas H. elegans subsp. cornuta had, in all collections, large crystals within fibriform cells (sometimes with smaller crystals), no crystals of any sort could be detected in any of the sections of H. heydeana. On the other hand, wood of $H$. heydeana is dark in color, a fact undoubtedly related to the abundance of dark-staining deposits in ray and axial parenchyma cells, as revealed by the photomicrographs (Figs. 4, 9-10, 12). The presence of thick-walled ray cells with bordered pits (Fig. 4) is to be expected in view of the occurrence of this phenomenon in H. elegans subsp. cornuta, Camissonia crassifolia, and Epilobium colchicum subsp. colchicum. The occurrence of axial parenchyma cell groups in H. heydeana (Fig. 10) is much like that in H. elegans subsp. cornuta, and emphasizes the generic distinctness of Hauya. Ray histology does not appear to change appreciably with age in $H$. heydeana, although such large trunks as those of $H$. elegans subsp. cornuta were not available, perhaps because this species does not form as large trees. The presence of starch in ray cells of $H$. heydeana (Fig. 4), conspicuously preserved because of embedding of the starch grains in the amorphous deposits, is to be expected for Onagraceae as a whole and was also observed in $H$. elegans subsp. cornuta. The two species are alike in the absence of septa in fibers, absence of interxylary phloem, and absence of tyloses. The gelatinous fibers of $H$. heydeana (Fig. 10) differ from the nongelatinous ones in H. elegans subsp. cornuta, although gelatinous fibers are very common in Onagraceae (Carlquist, 1975a). Pits on vessels of $H$. heydeana are probably vestured, but that vesturing is so fine that it appears only as a slight darkening of the edge of the pit aperture; scanning electron microscopy would be required for definitive demonstration.

Qualitatively, wood characteristics of $H$. heydeana are much like those of $H$. elegans subsp. cornuta, indicating an equally mesomorphic conducting system conformation. The changes from inside to outside of a log of H. heydeana in quantitative features are much like those of $H$. elegans subsp. cornuta or Fuchsia excorticata: vessels elements are wider, longer, and fewer per $\mathrm{mm}^{2}$ of transection in the outer wood. Rays are shorter in the outer wood of both species of Hauya, contrary to the increase in ray height in Fuchsia excorticata.

\section{Ecological Concepts}

In my survey of Onagraceae (Carlquist, 1975a), I used, for groupings of species, an index based upon the sum of mean vessel diameter and mean vessel element length. That index appeared to reflect accurately the ecology of onagra- 
TABLE 1. Ecological indices for woods of Onagraceae.

\begin{tabular}{|c|c|c|}
\hline Species & $\mathrm{V}$ & M \\
\hline \multicolumn{3}{|l|}{ Fuchsieae } \\
\hline Fuchsia boliviana Britton & 1.54 & 559 \\
\hline F. cyrtandroides J. W. Moore & 5.15 & 2,260 \\
\hline \multicolumn{3}{|l|}{ F. excorticata (J. R. \& G. Forst.) L. f. } \\
\hline inside & 1.08 & 280 \\
\hline outside & 2.28 & 741 \\
\hline F. fulgens DC. & 1.67 & 499 \\
\hline F. magellanica Lam. var. globosa (Lindl.) Bailey & 1.75 & 673 \\
\hline F. magellanica var. macrostemma (Ruiz \& Pavón) Munz & 1.39 & 489 \\
\hline F. paniculata Lindl. & 3.91 & 2,151 \\
\hline F. parviflora Lindl. & 0.52 & 245 \\
\hline F. splendens Zucc. & 1.28 & 591 \\
\hline F. tincta I. M. Johnston & 1.08 & 356 \\
\hline F. tuberosa Krause & 0.22 & 71 \\
\hline All Fuchsieae & 1.99 & 634 \\
\hline \multicolumn{3}{|l|}{ Lopezieae } \\
\hline Lopezia grandiflora Zucc. & 1.17 & 579 \\
\hline L. langmaniae Miranda & 2.07 & 797 \\
\hline L. longiflora (Decne.) Plitmann, Raven \& Breedlove & 5.79 & 1,847 \\
\hline L. lopezioides (H. \& A.) Plitmann, Raven \& Breedlove, Breedlove 7268 & 2.00 & 902 \\
\hline L. lopezioides, Breedlove 8052 & 2.96 & 929 \\
\hline L. miniata Lag. ex DC. subsp. miniata & 0.63 & 187 \\
\hline L. miniata subsp. paniculata (Seem.) Plitmann, Raven \& Breedlove & 1.21 & 439 \\
\hline L. racemosa Cav. subsp. moelchenensis Plitmann, Raven \& Breedlove & 0.32 & 86 \\
\hline L. racemosa subsp. racemosa & 0.86 & 237 \\
\hline L. riesenbachia Plitmann, Raven \& Breedlove & 0.46 & 155 \\
\hline L. semeiandra Plitmann, Raven \& Breedlove & 3.68 & 1,417 \\
\hline Lopezieae: shrubs combined & 2.70 & 961 \\
\hline Lopezieae: annuals, suffrutescent perennials combined & 0.67 & 215 \\
\hline
\end{tabular}

Onagreae

Calylophus hartwegii (Benth.) Raven subsp. pubescens (A. Gray)

Towner \& Raven

$0.14 \quad 26$

C. serrulatus (Nutt.) Raven

$0.13 \quad 18$

Camissonia californica Raven

$0.76 \quad 234$

C. crassifolia (Greene) Raven

$0.12 \quad 25$

C. cheiranthifolia (Hornem. ex Spreng.) Raimann $\quad 0.41 \quad 68$

$\begin{array}{lll}\text { C. megalantha (Munz) Raven } & 0.83 & 338\end{array}$

$\begin{array}{lll}\text { Clarkia xantiana A. Gray } & 0.35 & 119\end{array}$

Gaura biennis L.

G. longiflora Spach

$0.66 \quad 174$

$1.10 \quad 375$

G. parviflora Dougl.

G. sinuata Nutt. ex Sér.

$1.13 \quad 267$

G. villosa Torr. subsp. villosa

$\begin{array}{lr}0.14 & 15 \\ 0.52 & 134\end{array}$

Gongylocarpus fruticulosus (Benth.) Brandegee subsp. glaber

(Thomas) Carlquist \& Raven

0.53

120

G. rubricaulis Schlecht. \& Cham.

$\begin{array}{ll}0.53 & 120 \\ 0.75 & 271\end{array}$

Heterogaura heterandra (Torr.) Cov.

$0.69 \quad 197$

Oenothera deltoides Torr. \& Frém. subsp. howellii (Munz) Klein $\quad 0.81 \quad 237$

O. drummondii Hooker

$0.74 \quad 169$

O. elata H.B.K.

$1.19 \quad 353$

O. linifolia Nutt.

0.20

Xylonagra arborea (Kell.) Donnell Smith \& Rose subsp. wigginsii Munz 1.68 
TABLE 1. (continued)

\begin{tabular}{lrr}
\hline \hline \multicolumn{1}{c}{ Species } & $\mathrm{V}$ & $\mathrm{M}$ \\
\hline $\begin{array}{l}\text { Jussiaeeae } \\
\text { Ludwigia octovalvis (Jacq.) Raven, Raven 6571 }\end{array}$ & 0.73 & 313 \\
L. octovalvis, Raven 18670 & 0.67 & 287 \\
L. uruguayensis (Cambess.) Hara & 1.54 & 548 \\
$\quad$ Epilobieae & & 242 \\
Epilobium colchicum Alboff subsp. colchicum & 1.32 & 122 \\
E. paniculatum Nutt. ex Torr. \& A. Gray & 0.52 & 17 \\
E. (Zauschneria) canum subsp. canum & 0.11 & \\
Hauyeae & & 1,328 \\
Hauya elegans DC. subsp. cornuta (Hemsley) Raven \& Breedlove, & 3.20 \\
$\quad$ Breedlove 6432 & 3.38 \\
H. elegans subsp. cornuta, Breedlove 10589 & 2.96 & 1,153 \\
H. elegans subsp. cornuta, Carlquist VI-1958 & & 1,270 \\
Hauya heydeana Donnell Smith & 1.43 & 688 \\
$\quad$ inside & 3.50 & 1,771 \\
Hautside & 2.89 & 1,242 \\
\hline
\end{tabular}

ceous species and species groups. More recently (Carlquist, 1977; Carlquist \& DeBuhr, 1977) I have constructed additional indices for wood ecology. One of these, which may be termed "vulnerability" ( V in Table 1) consists of the mean vessel diameter divided by the mean number of vessels per $\mathrm{mm}^{2}$ of transection. Although vessel diameter and number of vessels per $\mathrm{mm}^{2}$ are roughly inversely proportional for mesophytes (Carlquist, 1975b: 183), xerophytes tend to have narrower vessels and more numerous vessels per $\mathrm{mm}^{2}$ than would be expected on the basis of study of mesomorphic woods only, as shown by the desert shrubs included in the graph just cited. This "redundancy" of vessels in xerophytes provides a conductive tissue in which a large number of vessels could be disabled by air embolisms without appreciably lessening conductive capacity. Thus a low value for "vulnerability" can be construed as a high degree of "safety" under water stress conditions and, therefore, xeromorphy.

Vessel element length seems a sensitive indication of xeromorphy or mesomorphy (Carlquist, 1975b). Although one could argue that vessel diameter and number of vessels per $\mathrm{mm}^{2}$ are somewhat interrelated, vessel element length is controlled entirely independently, by length of fusiform cambial initials. Long vessel elements can be hypothesized to occur in mesomorphic conductive systems, short ones in xeromorphic woods. Therefore, multiplying the "vulnerability" index by mean vessel element length yields a figure which is termed "mesomorphy" ( $\mathrm{M}$ in Table 1) here. The higher the value of this value, the greater the hypothetical mesomorphy of the wood. The family Penaeaceae illustrated that this index is reliable on the basis of known species (Carlquist \& DeBuhr, 1977). It also appears to be reliable in Onagraceae. Because Onagraceae occupy a notably wide range of ecological situations, I am presenting here the two indices for all species of Onagraceae studied to date (Table 1).

One can interpret these indices only within ranges. A "V" figure markedly 
below 1.0 (perhaps $0.1-0.5$ ) would indicate a high degree of xeromorphy (Carlquist, 1977), and the lower limit for true mesomorphy would be close to 3.0.

With respect to the " $\mathrm{M}$ " index, true xeromorphy is indicated probably by a level below 30.0. In Tremandraceae, values range between 15.4 and 45.0 (Carlquist, 1977), and the highest "M" value in Penaeaceae was 587 (Carlquist \& DeBuhr, 1977). Small sampling differences can alter values of these indices, obviously. Future development of these indices will indicate their potential validity in ecological and physiological analyses of dicotyledon families. However, the $\mathrm{V}$ and $\mathrm{M}$ indices show the same sequence (Hauyeae; Fuchsieae; large shrubby Lopezieae; annual or suffrutescent Lopezieae; annual Onagreae; perennial Onagreae) as was demonstrated by the vessel diameter + vessel element length figure (Carlquist, 1975a). The latter figure, however, was higher for the Jussieeae than for Hauyeae, a fact I related to the hydrophytic habit of Jussieeae. However, the $\mathrm{V}$ value for Jussieeae is low, which one might not expect in a hydrophyte. Perhaps the fact that Jussieeae grow in seasonally wet but often drying environments explains why they have xylem that combines low vulnerability with mesomorphy. A relatively high amount of redundancy in vessels in Jussieeae would cope well with the drying out of habitats. The high $\mathrm{V}$ value for Hauyeae (and, to a lesser extent, Fuchsieae) would correlate with lack of any marked water stress in the habitats of these species.

If one can interpret the $M$ value for inside wood versus outer wood in a log, Fuchsia excorticata and both species of Hauya begin with appreciably less mesomorphic wood structure and increase in mesomorphy, as well as vulnerability, with age. This would not be unexpected in view of my earlier (1975b) considerations. However, if this phenomenon does prove to be widespread in dicotyledons, we must conclude that vascular plants tend to have less vulnerability, less mesomorphy in earlier-formed xylem. If the root system of a woody dicotyledon would be expected to experience more severe fluctuation in water availability (nearer the soil surface) than when a tree is older, this would be logical. However, study of additional species would be valuable in this respect. Future application of these indices will indicate their potential validity in physiological analyses of dicotyledon families. Onagraceae is, however, a critical family in this respect, and appears to reflect the broad range of ecology of the family as a whole, and the ecology of individual species and of growth forms, as discussed earlier (1975a) and here.

\section{Literature Cited}

Bailey, I. W., \& W. W. Tupper. 1918. Size variation in tracheary cells. I. A comparison between the secondary xylems of vascular cryptogams, gymnosperms, and angiosperms. Proc. Amer. Acad. Arts 54: 149-204.

Butterfield, B. G. \& B. A. Meylan. 1973. Scanning electron micrographs of New Zealand woods. 3. Fuchsia excorticata (J. R. \& G. Forst.) Linn. f. New Zealand J. Bot. 11: 411419.

Carlquist, S. 1975a. Wood anatomy of Onagraceae, with notes on alternative modes of photosynthate movement in dicotyledon woods. Ann. Missouri Bot. Gard. 62: 386-424. Berkeley.

975b. Ecological Strategies of Xylem Evolution. Univ. of California Press, - 1977. Wood anatomy of Tremandraceae: phylogenetic and ecological interpretations. Amer. J. Bot. 64: 704-713. 
\& L. DeBurr. 1977. Wood anatomy of Penaeaceae (Myrtales): comparative, phylogenetic, and ecological implications. Bot. J. Linn. Soc. (in press).

Moss, E. H. 1936. The ecology of Epilobium angustifolium with particular reference to rings of periderm in the wood. Amer. J. Bot. 23: 114-120. 


\section{$2 \mathrm{BHL}$ Biodiversity Heritage Library}

Carlquist, Sherwin John. 1977. "Wood Anatomy of Onagraceae: Additional Species and Concepts." Annals of the Missouri Botanical Garden 64, 627-637. https://doi.org/10.2307/2395258.

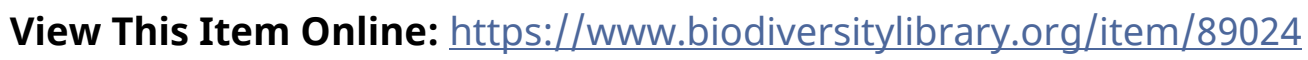

DOI: https://doi.org/10.2307/2395258

Permalink: https://www.biodiversitylibrary.org/partpdf/40263

\section{Holding Institution}

Missouri Botanical Garden, Peter H. Raven Library

\section{Sponsored by}

Missouri Botanical Garden

\section{Copyright \& Reuse}

Copyright Status: In copyright. Digitized with the permission of the rights holder.

License: http://creativecommons.org/licenses/by-nc-sa/3.0/

Rights: https://biodiversitylibrary.org/permissions

This document was created from content at the Biodiversity Heritage Library, the world's largest open access digital library for biodiversity literature and archives. Visit BHL at https://www.biodiversitylibrary.org. 